Document downloaded from:

http://hdl.handle.net/10251/47418

This paper must be cited as:

Ward, FA.; Pulido-Velazquez, M. (2012). Economic Costs of Sustaining Water Supplies: Findings from the Rio Grande. Water Resources Management. 26(10):2883-2909. doi:10.1007/s11269-012-0055-8.

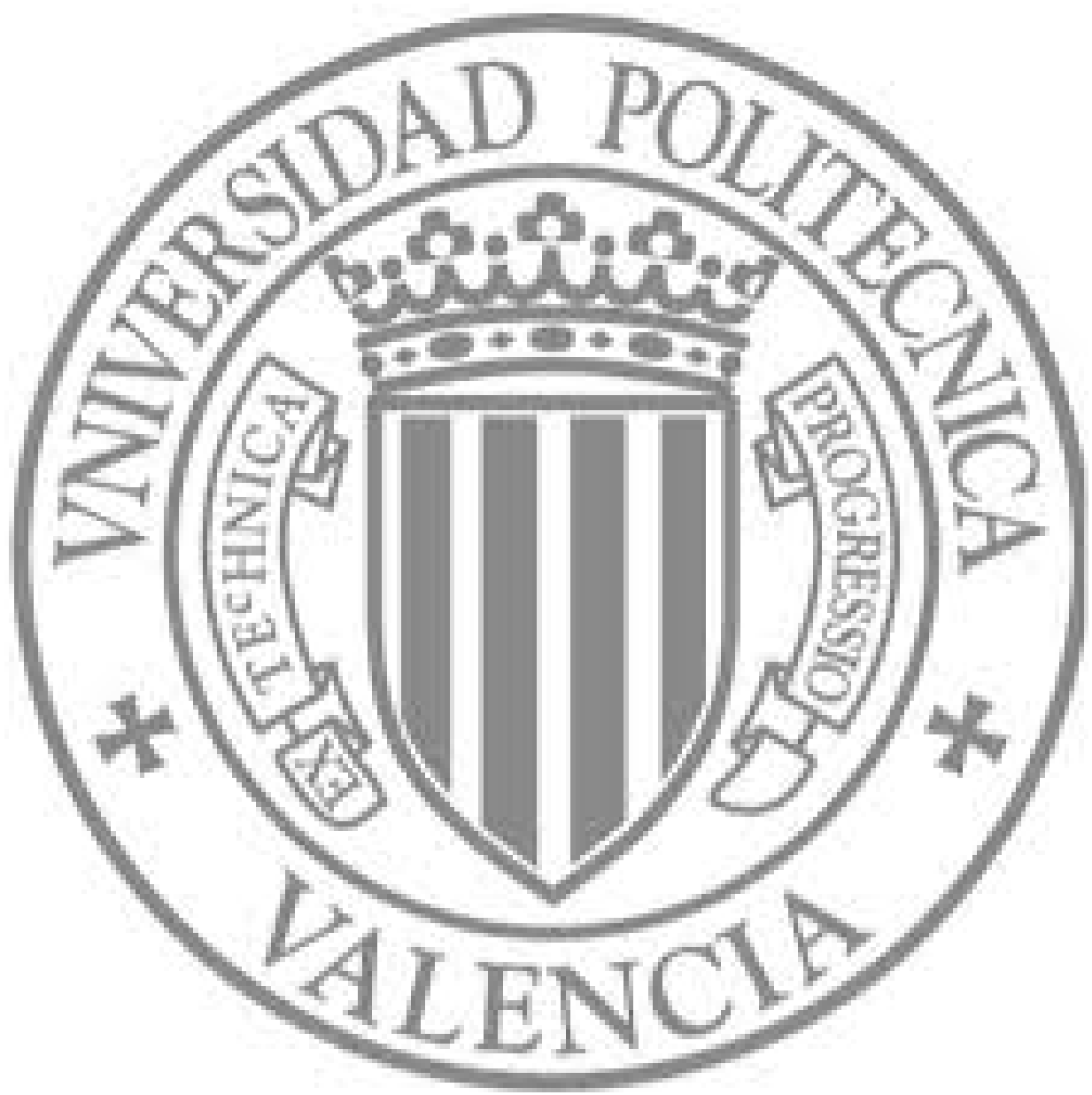

The final publication is available at

http://dx.doi.org/10.1007/s11269-012-0055-8

Copyright Springer Netherlands 


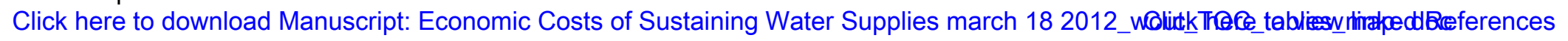

1

2

3

4
Economic Costs of Sustaining Water Supplies: Findings from the Rio Grande

Frank A. Ward

Professor

Department of Agricultural Economics and Agricultural Business

New Mexico State University

Las Cruces, NM 88003

e-mail: fward@nmsu.edu

Manuel Pulido Velázquez

Dpto. Ingeniería Hidráulica y Medio Ambiente

ETSI Caminos, Canales y Puertos (School of Civil Engineering)

Universidad Politécnica de Valencia

Camino de Vera s/n; 46022 - Valencia - SPAIN

Phone: +34-963879616; Fax: +34-963877618

e-mail: mapuve@hma.upv.es ; URL: http://www.upv.es/aquatool

March 18, 2012

The authors are grateful for financial support for this work by the New Mexico Agricultural Experiment Station and by the European Community $7^{\text {th }}$ Framework Project GENESIS (226536) on Groundwater Systems 
Economic Costs of Sustaining Water Supplies: Findings from the Rio Grande

\begin{abstract}
Water claims in many of the world's arid basins exceed reliable supplies. Water demands for irrigation, urban use, the environment, and energy continue to grow, while supplies remain constrained by unsustainable use, drought and impacts of climate change. For example, policymakers in North America's Upper Rio Grande Basin face the challenge of designing plans for allocating the basin's water supplies efficiently and fairly to support current uses and current environments. Managers also seek resilient institutions that can ensure adequate supplies for future generations. This paper addresses those challenges by designing and applying an integrated basin-scale framework that accounts for the basin's most important hydrologic, economic, and institutional constraints. Its unique contribution is a quantitative analysis of three policies for addressing long term goals for the basin's reservoirs and aquifers: (1) no sustainability for water stocks, (2) sustaining water stocks, and (3) renewing water stocks. It identifies water use and allocation trajectories over time that result from each of these three plans. Findings show that it is hydrologically and institutionally feasible to manage the basin's water supplies sustainably. The economic cost of protecting the sustainability of the basin's water stocks can be achieved at 6 - 11 percent of the basin's average annual total economic value of water over a 20 year time horizon.
\end{abstract}


Economic Costs of Sustaining Water Supplies: Findings from the Rio Grande

\section{Background}

Twenty-first century decision-makers face an array of challenges in the search for sustainable environmental policies. In most river basins, actions taken for one use, at one place, or in one period affect water quantity or quality for another use, at another location, or in another period. For this reason there is considerable need for integrated water resources management (IWRM) plans that couple the physics governing water stocks and flows with economic and institutional factors affecting water's demands and supplies. Decision makers need integrated plans that help them identify the full range of current and future consequences associated with various management strategies and growing resource demands in the face of current or altered climate. A water manager may need access to an integrated framework to evaluate effects of drought on water supply as well as its impacts on other systems such as key ecological assets, agriculture, urban water use, and economic development.

Effectively managing complex water systems for the benefit of current and future generations is an ongoing challenge facing contemporary water managers. A single, integrated basin-scale plan presents several advantages for managers, farmers, and the water-using public in the search for better performing institutions:

- It offers a clear view of water resources in a river basin, where water goes, how it's used, and how much remains available for further use.

- It identifies opportunities for saving water and increasing its economic productivity.

- It pinpoints times and places where water can be transferred from lower- to higher-valued uses. 
- It helps identify opportunities to reduce evaporation, pollution, or water flows into nonretrievable sinks.

- It helps conceptualize and test for hydrologic and economic impacts of proposed actions in several time periods for many uses.

- It identifies economically efficient ways to improve the productivity of water and reduce its waste.

- It provides a language and forum for debating water policy choices.

- It can reduce water conflicts by presenting information used to support decisions.

Many researchers have recognized the power of basin scale analysis, and several basin-scale analyses have been developed and applied since the mid 1990's. Booker and Young (1994) and Booker (1995), in two celebrated studies, developed and applied an integrated hydrologic-economic-institutional analysis of the Colorado River Basin covering its seven US states. More recently, several kinds of hydro-economic water resource system management models have been published: large-scale integrated river basin scale models applied to predict economic impacts of policies for managing droughts (e.g., Characklis et al., 1999; Booker et al., 2005; Ward et al., 2006); assessments of the economic value of streamflow by location in a basin (e.g., Brown, 1990; Willis and Whittlesey, 1998; Newlin et al., 2002, Pulido-Velazquez et al., 2006; Jenkins et al., 2006); optimal system operation (e.g., McCarl et al., 1999; Watkins and McKinney, 1999; Pulido-Velazquez et al., 2004); water allocation and policy options (e.g., Letcher et al., 2004); water transfers and water markets (e.g., Rosegrant et al., 2000, Draper et al., 2003; Knapp et al., 2003; Ward et al., 2006; Jenkins et al., 2006), analysis of infrastructure investment (e.g., Cai and Rosengrant, 2004; Ringler et al., 2004, Cai et al., 2006), analysis of trade-offs among competing uses 
(Ward and Lynch, 1997; Burke et al., 2004; Watkins and Moser, 2006), and assessments of regional economic impacts of climate change and its adaptation (e.g., Tanaka et al., 2006).

This Journal has blazed new trails in recent years by publishing numerous applications of IWRM to inform water policy debates on workable measures to promote sustainable water resource systems. For example, Zarghaami (2006) showed how an IWRM approach could solve irrigation management problems and as reduce social conflicts in northern Iran. Flugel (2007) developed an integrated basin scale analysis applied to inform food and environmental policy debates for the Tisza River basin that rises in Ukraine. Murad et. al (2007) addressed the problem of scarce water in the United Arab Emirates as limiting sustainable development. The authors found that water scarcity problems there could be alleviated by implementing an IWRM strategy that including development of non-conventional water resources. Pascual (2007) found that assessments of social, environmental, and economic impacts, as advocated by the European Commission could support better administration to IWRM principles. Schulze (2007) characterized differences between IWRM in Lesser Developed Countries (LDCs) and Developed Countries (DCs) by outlining characteristics of LDCs and DCs that shape their respective needs for IWRM. Van der Keur, et. al (2008) characterized uncertainty in the different stages of the IWRM process with respect to sources, nature and type of uncertainty, and applied their framework to the IWRM process to inform policy debates in the Rhine Basin. El-Naqa and Al-Shayeb (2009) presented the status of groundwater resources in Jordan and identified major management challenges from an IWRM view.

Molina et al (2009) applied IWRM to the water system of the Altiplano region in Murcia, Spain, where aquifer water extraction exceeds recharge for a highly profitable irrigated region. Prodanovic and 
Simonovic (2011) presented a model for operational support of integrated water resources management in the Upper Thames watershed, Ontario, Canada. Results indicated that water supply will be a limiting factor for future growth and development. As these examples show, considerable advances have been made in basin scale analysis in recent years. Despite these impressive achievements, we have been unable to find any published work that has used a comprehensive basin scale approach to examine the economic cost of reducing current water uses to support more sustainable water supplies. We also have found few if any published works that have identify the kinds of policies that could be implemented to sustain those supplies. Finally, we are also aware of no works that conduct an analysis of how to manage transboundary river basin as a single unified resource that also looks for a management scheme that integrates water needs and economic values of water for the various waterusing sectors. The sectors needed for such a comprehensive analysis include economic production of different types, environmental needs, and human direct water consumption demands.

This paper addresses those gaps by designing and applying an integrated basin-scale constrained optimization framework that identifies water allocation and use patterns for the Upper Rio Grande Basin of North America (the Basin). This paper's novel contribution is a comprehensive basin scale analysis of the impact of three policies for achieving sustainability goals for the Basin's most important reservoirs and aquifers. It identifies changes in water use patterns, water allocation, and the level and distribution of economic benefits produced by water that result from each of three policies that address sustainability targets for the basin's water stocks. The approach taken by the paper is practical: it focuses on the costs and benefits to be derived from various management schemes. It is based on the need faced by water managers and political leaders who wish to focus on practical and realistic measures to achieve sustainable water supplies in a complex river basins containing a wide range of interdependent water uses. 


\section{Study Area}

\subsection{Rio Grande Basin}

The Basin flows from its headwaters in southern Colorado to about 70 miles south of the US-Mexico border cities of El Paso, Texas - Ciudad Juárez, Mexico (Map). Surface water and groundwater from the river system meets the primary water needs of three major cities of Albuquerque, New Mexico and El Paso, Texas in the US in addition to the Mexican city of Ciudad Juárez. The Basin supports a rapidly growing population of more than three million people, extensive irrigated agriculture, and fish and wildlife habitat in Colorado, New Mexico, Texas, and the Mexican state of Chihuahua. Depending on the year, about 85 percent of the consumptive use of water in the Basin is used for irrigated agriculture. Only about 47 percent the water applied to crops is consumed under current conditions as ET. The percentage that is applied but not consumed in the irrigation field where water is applied is an important water source for groundwater recharge, riparian habitat, and return-flows to downstream human and environmental uses in current and future generations.

The Basin's water managers face several international, federal, regional, state, and regional institutions that regulate water flows and allocations. These include an international treaty between Mexico and the US; the Rio Grande Compact among Colorado, New Mexico and Texas, engagement of a number of US federal agencies, state statutes, ongoing litigation, and numerous water delivery contracts. While existing institutions for allocating water have served the basin well in recent decades, there remains considerable interest in the design and evaluation of alternative potentially more resilient institutions that could better meet the needs of the Basin's current and future residents.

\subsection{Sustainability Issues}


Basin managers and policymakers confront numerous water issues and choices issues that require a comprehensive sustainable basin scale IWRM view. Examples include:

- $\quad$ third-party impacts of water transfers

- $\quad$ economics of developing and using alternative water sources; for example, desalination, recycling, or reuse for urban and environmental water supplies.

- $\quad$ wastewater reuse for irrigated agriculture

- improved agriculture irrigation efficiencies and shifting to higher value crops or more waterconserving irrigation technologies

- design of resilient institutions to address climate change

- $\quad$ economic and hydrologic impact of climate change on current and potential water decisions

These and other policy debates can be informed more comprehensively with a basin scale view than with analysis conducted for a single sector, location, or period. The Basin's demands for water continue to grow, especially in the urban areas of Albuquerque, El Paso, and Ciudad Juárez. As environmental and urban demands increase in the face of constant or decreasing supplies, various governments, farmers, urban planners, and commercial developers are looking for ways to access and manage increasingly scarce water. Across the Rio Grande from Ciudad Juárez, El Paso water managers continue to examine measures to manage growing demands for water. The present El Paso Texas - Las Cruces New Mexico area population of about 2 million is expected to triple in the next 25 years. The only renewable water source in the lower part of the basin is the Rio Grande itself. These few examples emphasize the importance of the continued search for resilient institutions that would promote sustainable use of the Basin's water. Approaching these issues objectively can be handled more comprehensively with a basin scale approach in which all water uses, use locations, water sources, and time periods are handled simultaneously in a unified analytical framework. 


\section{Water Institutions}

Water institutions are structures and mechanisms of social order governing the behavior of a set of individuals within a group. Often implemented as written or informal rules, they are instruments for defining, constraining, or adjusting individual behavior to improve society's current or future welfare. Four institutions in the Basin stand out from the rest in importance: the U.S. Mexico Treaty of 1906, the U.S. Endangered Species Act of 1973, the Rio Grande Compact of 1938, and the New Mexico-Texas water sharing convention.

\subsection{International}

Water allocations and use patterns in many of the world's basins are constrained and defined by various trans-boundary water sharing agreements. Finding ways to meet obligations specified by existing water sharing agreements, where they exist, is a major source of political tension in the world's arid basins, and carries with them considerable economic implications. For an upstream political unit to meet its formal or informal water delivery obligations imposes a considerable economic cost. Failure to meet it can impose high economic costs borne by the downstream region or country. For the Basin, a significant trans-boundary agreement is the U.S. Mexico Treaty of 1906, which requires that the U.S. deliver 60,000 acre-feet ( 1 acre foot $=1233$ cubic meters) per year to Mexico, except in times of extraordinary drought. Our framework requires the U.S. to deliver 60,000 acre-feet to Mexico in all years and in all drought conditions.

\subsection{National}

The U.S. Endangered Species Act (ESA) provides protection for various species of fish, wildlife and plants that are listed in the U.S. as threatened or endangered. Provisions are made for listing species, for 
recovery plans, and for designation of critical habitat for listed species. The ESA prohibits federal agencies from actions that jeopardize the continued existence of any endangered species. It prescribes measures for federal agencies to follow when taking actions that may jeopardize listed species. Its purposes are to: provide measures for conserving the ecosystems upon which endangered and threatened species depend; provide programs for conserving those species; and take steps needed to achieve the purposes of international treaties and conventions. A biological opinion issued by the U.S. Fish and Wildlife Service in 2001 estimates that bringing the endangered Rio Grande Silvery Minnow (the Minnow) back from the brink of extinction requires at least 50 cubic feet per second (cfs) of yearround streamflow at the San Acacia gauge near Socorro, New Mexico (Map). Our analysis requires annual flows at that gauge to exceed a critical level required for the minnow's survival, about 240,000 acre-feet per year under recent operating conditions.

\subsection{Inter-regional}

Many of the world's river basins contain rivers that cross international boundaries. In many cases, formal or informal transboundary water sharing agreements have been established. In the western U.S., twenty two trans-boundary water sharing agreements have been established as interstate compacts. Typically, under a compact arrangement in this part of the world, two or more states agree to share a river's natural flow, in which the federal government serves as the referee. The first such agreement was the Colorado River Compact, signed by the Colorado River Basin states, at Bishop's Lodge, New Mexico, in 1922.

The Rio Grande Compact (the Compact) - signed in 1938 by Colorado, New Mexico, and Texas - divides the annual flow of the Rio Grande. The Compact was established so that each state receives more water in wetter years and less in drier years. Under the Compact, Texas bears the largest percentage of flow 
shortages in dry years, but it also has the largest amount of storage to capture high flows in wet years. Colorado has the least reservoir storage capacity, so it negotiated the highest percentage of natural runoff in the driest years to compensate for its limited reservoir storage. Articles III and IV of the Compact oblige Colorado to deliver water at the Colorado-New Mexico state line ( Map). Article $\mathrm{V}$ of the Compact and the 1948 resolution of the Compact require New Mexico to deliver water to Texas measured at the outflow of Elephant Butte Reservoir. New Mexico's delivery requirement to Texas is based on New Mexico's annual supply, defined as total flows at the Otowi stream gauge, north of Santa Fe, New Mexico (New Mexico Water Resources Research Institute, 2006).

\subsection{Intra-regional}

Many western U.S. river basins as well as a number of other countries have established informal intrabasin water sharing agreements, by which historical water use patterns are used as a framework for sharing water, and for influencing the future course of economic and water use growth. Since the early 1950's, the U.S. states of New Mexico and Texas have agreed to share water delivered by the Rio Grande Project, for which outflows occur at Caballo Reservoir (Map). Based on historical agricultural land in production in New Mexico and Texas at the time of the Rio Grande Project's construction, U.S. lands in New Mexico receive deliveries of up to $57 \%$ of any year's allocation, while lands in Texas have received up to $43 \%$, for a total of up to $100 \%$. In recent years, much of the current Texas allocation actually goes to urban users serviced by the City of El Paso. Recently west Texas irrigators have found it more profitable to rent or sell water or water rights to the City of El Paso rather than using it for economically marginal crops. When total use for any given year is less than $100 \%$ of available project storage, the unused part is held in project storage at either Elephant Butte or Caballo Reservoirs for future use. A 2009 agreement between southern New Mexico and west Texas water users increased the incentive to 
hold unused water in those two storage reservoirs for the future rather than using it immediately on low valued crops.

\title{
4 Methods
}

Our approach for analyzing the economic costs of securing sustainable water supplies is based on the development of a dynamic constrained optimization framework. An empirical model is developed and applied that shows results of a policy that allocates stocks and flows of water over time, space, and use. The objective is to maximize water's discounted net present value subject to various hydrologic and institutional constraints. In measuring the economic value of water, we account for the fact that the economic value of water comes from the many uses to which water can be put in satisfying human wants and needs, including the satisfaction received from water based recreation at the Basin's reservoirs. The economic value of water is defined as the amount that a rational user of a publicly or privately supplied source of water is willing to pay. Economic values for different water uses are defined according to their marginal value in production, consumption, or state of the environment. There is an extensive literature on valuation of water to determine water demands for its many uses and many dimensions of quality improvement, recently reviewed and updated by Young (2005). Valuation approaches for irrigation, urban use, and outdoor recreation are described briefly subsequently.

\author{
4.1 Integrated Management of Transboundary Waters \\ Internationally, numerous communities who share supplies of transboundary waters face a common \\ challenge: continued population growth and economic development will increase water demands for \\ energy production, irrigation, industry and domestic use at the regional level while key ecological assets \\ need to be maintained or restored. Seen in this light, the pressure on freshwater resources in these \\ transboundary basins will increase unless active measures are taken to secure more economic and
}


environmental value from existing water resources for all the communities (e.g., states or countries) tied by the common water. Especially in river basins like the Tigris-Euphrates, Jordan, Nile, and Amu Darya, integrated transboundary water resource management presents an important mechanism for promoting the common agenda of peace, trust, stability and economic development.

The development and application of analytical capacity to inform IWRM helps to identify options to secure more benefits from water resources development and management in the world's transboundary basins. While our analysis was limited to the Rio Grande Basin of North America, its approach has implications for transboundary waters everywhere where there are debates over the sharing of water or sharing benefits from water. Both water sharing and benefit sharing have the potential to promote regional cooperation, secure economic and political stability, and opening up opportunities for cooperative economic development in communities often hydrologically, politically, or culturally isolated from each other. Results from our IWRM exercise illustrate the common frame of reference that could provide stakeholders access to a consistent set of basin scale information. This common frame of reference has the potential to build understanding and seek cooperative solutions on regional water development challenges.

\subsection{Data}

\subsubsection{Water and Water Use Patterns}

The Basin has four major US agricultural producing areas (Map): they include the Rio Grande Water Conservation District (2011) in the San Luis Valley (SLV) of southern Colorado; the Middle Rio Grande Conservancy District (2011) in central New Mexico (MRGCD); the Elephant Butte Irrigation District (2011), in southern New Mexico (EBID); and the El Paso County Water Improvement District\#1 (2011) in far west Texas (EP\#1). Each of these areas uses surface water for agricultural production; however, only 
SLV and EBID pump significant amounts of groundwater for irrigation. MRGCD and EP\#1 have access to groundwater but neither has developed much groundwater pumping infrastructure for irrigation as of 2012. The Basin's two US urban water use areas in the model are the City of Albuquerque, New Mexico (2011) and the El Paso Water Utility (2011).

Modeled flows include headwaters inflows (supplies), impacts of groundwater pumping on streams and aquifers, and net reservoir releases from storage, pumping from aquifers, irrigation and urban diversions, crop water ET, aquifer recharge, groundwater flow to or from the river, surface water return flow to the river, and reservoir evaporation. The model includes major functions that influence streamflow at each node as well as impacts of each important activity upstream of that node. The mass balance for reservoirs is given by starting storage minus reservoir releases plus river inflows to the reservoir minus evaporation. For groundwater storage changes in any period, the stock of groundwater is represented through effects of current and past seepage, water applied to crops, and water pumped for irrigation and urban uses. Work is ongoing to develop of a set of unifying groundwater equations implemented at the basin scale through a US Geological Survey MODFLOW type of mechanism with more precise linkages governing stream-aquifer interactions.

\subsubsection{Economic Value of Water in Alternative Uses}

The integrated basin analysis is formulated as a mathematical optimization of the Basin's water allocations using the General Algebraic Modeling System (GAMS). The integration of economic, hydrologic, and institutional characteristics provides a mechanism for conducting analyses of various policy choices with complex impacts on the hydrology, agronomy, and economics of a river basin (e.g., Ward and Pulido-Velazquez, 2008; Gürlük and Ward, 2009). 
The value of urban water use is measured as revenue collected by the utility water supplier plus any unpriced consumer surplus (Ward and Pulido-Velazquez, 2008). Urban use produces an economic benefit by consuming water. Benefits and costs were measured for urban use at the Basin's two important U.S. cities: Albuquerque, New Mexico, and El Paso, Texas. We adapted the empirical demand elasticity estimates from the study of Michelsen et al. (1998) to the climatic and demographic conditions of Albuquerque New Mexico and El Paso Texas. In that previous study, seven study areas were selected in southern California, Colorado, and Arizona. The absolute value of price elasticities varied from a low of about 0.05 to a high of about 0.20 for summer outdoor landscape use. For each city, a linear demand schedule was specified to pass through the water use and price combination for 2010 , in which the slope of that schedule was chosen to be consistent with the above price elasticity at that point. We used the integral of the marginal benefits of water use to measure total benefits of urban use. A linear demand function results in a quadratic total benefits function, for which those total benefits are maximized at the level of water consumption that occurs at a zero price (zero marginal benefit).

The economic value of the water environment is measured by the willingness to pay for water based recreation in the Basin's six major reservoirs, based on a regional travel cost model (Ward et al., 1997), updated with visitation data collected in 2003 at several New Mexico State Parks. The economic value of water in agriculture is measured by its contribution to producer net income. Our economic analysis of irrigation rests on a foundation of farm level economics. The farm economics is analyzed thorough the use of enterprise budgets (e.g., Hawkes and Libbin, 2011). They summarize the economics of irrigated agriculture in the Basin, and are published by the respective three state land grant universities agricultural extension services: Colorado State University, New Mexico State University, and Texas A\&M University. The budgets contain detailed financial information regarding flood-irrigated crop production, including crop acreage, equipment, crop production processes, and overall crop cost and return 
summaries. The published budgets typically contain detailed financial data for agricultural production, typically based on flood irrigation, by far the most common irrigation technology used in the Basin.

\subsection{Model Development}

The Basin's IWRM model was developed to bring the region's hydrology, agronomy, economics, and institutions within a single framework for policy analysis. The model starts with the basic water supply, which includes all major tributaries, interbasin transfers, and hydrologically connected groundwater. Current and projected water demands for the model's 20 year time horizon include agricultural demands for the basin's major irrigated areas, urban demands for Albuquerque and El Paso, recreation at all major reservoirs, and streamflow requirements for endangered species. The model is formulated to maximize discounted net present value over water uses and environments. It sums benefits from water diversions for off-stream uses plus environmental values of reservoir-based recreation. Constraints are used to characterize the basin's hydrology and institutions. In the model, reservoir contents, water applications, water return flows, groundwater pumping, aquifer recharge, and water uses are optimized over the model's time horizon, based on a stochastic representation of headwater inflows with means and variances of historical inflows, adjusted for a future of climate change in which future mean inflows are reduced, while maintaining historical variances.

The model accounts for decisions made by water users that support both water use and the water environment. Economic benefit functions are defined for the basin's four major farming regions, for urban users in the two US cities described above, ${ }^{1}$ and for water based recreation in the basin's six most important reservoirs. The model accounts for irrigation decisions by the use of economic data from farm

\footnotetext{
${ }^{1}$ The use for urban water is specified as a linear demand functions, calibrated to match recently estimated use levels and price elasticities of demand for each city. Demands are satisfied to meet growing demands in the face of growing populations. Population growth rate projections used for our analysis for the two cities are: Albuquerque at 2.4 percent per year and El Paso at 3.8 percent per year. Costs of urban water supply include costs of pumping, treating, and delivering the water.
} 
enterprise budgets. On farm irrigation decisions are based on irrigators choosing a crop mix and a quantity of surface and groundwater for known crop prices, crop yields, farm production costs, and the price of water. Changes in the price or availability of water alter land in production, farm income, and crop mix.

The integrated framework allows analysis of alternative water management proposals. It accounts for physical interactions among uses (agricultural, urban, streamflow, and environmental), storage (reservoirs and aquifers), flows (diversions, pumping, applications, seepage, and return flows), and losses (field, canal, conveyance, and reservoir evaporation). Booker et al (2005), Ward et al (2006), Ward and Pulido-Velazquez (2008) present detailed mathematical documentations of earlier versions of the model applied to the Rio Grande Basin. While the model was originally developed to applied to policy debates in the Rio Grande Basin, it was designed to be adaptable with minimum structural change to other basins, geographic configurations, land tenure arrangements, cultures, legal systems, and formal and informal water allocation rules. To date, the original Rio Grande Basin model has been successfully adapted several other basins. These include Egypt's use of the Nile (Gohar and Ward, 2010) to the Nilufer Basin in Turkey with mathematical documentation (Gurluk and Ward, 2009) and to the Balkh Basin in Afghanistan (Torell and Ward, 2010), with ongoing but as yet unpublished work in the Amu Darya and Tigris-Euphrates Basins.

\subsection{Total Economic Efficiency of a Policy Proposal}

A significant question facing water policymakers who wish to analyze impacts of decisions at the basin scale centers on the measurement of economic efficiency gains produced by a proposed water decision for a given climate scenario. We use a method that accounts for economic efficiency by computing four 
important kinds of benefits and costs for each location in the basin where economically important values of water occur.

For each of the nodes described above, our model calculates (1) use-related benefits, (2) use-related costs, (3) environmental benefits, ${ }^{2}$ and (4) environmental costs. For any node, total net benefits in a single period equal total benefits minus total costs. Total benefits equal the sum of (1) and (3), while total costs are the sum (2) and (4). Based on this computation for any node and for any program of measures, we calculate the discounted NPV of use-related net benefits added to environmental net benefits, summed over uses and time periods. Applying this method to calculate and compare userelated net benefits to those net benefits arising from a quality environment, we measure total opportunity costs of any program of measures as the efficiency change it brings about, positive or negative. Compared to a given baseline program of measures, the total economic efficiency change, positive or negative, resulting from a different program is the present value of the total change in net benefits.

\subsection{Analysis of Three Policies}

The model constrains water allocations to produce outcomes consistent with the four water institutions described above. These institutions include: (1) International Treaty, (2) Federal Law; (3) Interstate Compact, and (4) Instrastate Agreement. We characterize these four institutions as the "Law of the River." In the model, solutions representing water allocations under the Law of the River combined with any of the three programs described below are obtained through a one shot optimization. For each policy the model maximizes basin-wide discounted net present value at a two percent discount rate, subject to constraints defined by the Law of the River in addition to requirements of the basin's

\footnotetext{
${ }^{2}$ Environmental recreation benefits at each reservoir are specified as a quadratic function of reservoir area.
} 
hydrologic continuity for surface water and groundwater. These four institutions place limits on storing, moving, pumping, evaporating, and applying water, while allowing the model to compare three alternative programs: unsustainable natural capital, sustaining natural capital, and renewing natural capital, all of which are described below.

\subsubsection{Unsustainable Natural Capital}

A policy of unsustainable natural capital promotes natural capital (water) being used up faster than it can be replenished. Sustainability requires that human activity uses only nature's water resources at a rate at which it can be replenished naturally. For purposes of this paper we define unsustainable institutions as those that reduce the Basin's long-run water supply stocks. This concept is implemented by the simple method of placing no requirement whatsoever on terminal reservoir storage volumes or aquifer stocks. Reservoirs and/or aquifers can be run down as low as desired in the terminal year with no regard for future generations. The only current economic cost that direct groundwater users confront when pumping aquifers unsustainably is the increased pumping costs incurred by that pumping. Additional pumping takes place as long as the economic value of the pumped water exceeds the additional cost of the pumping and as long as the current installed pumping capacity is enforced.

Beyond these marginal costs, there are no special incentives to conserve water for the future or to internalize the external pumping costs. External impacts in groundwater use are pervasive (National Research Council, 1997; Livingston and Garrido, 2004). When resource users do not bear the full costs of their actions, private and social costs diverge. In addition the individual pumper is unable to capture the future value of the resource, and there is a perverse incentive to develop and use the resource more intensively than is economically efficient from the view of social costs and benefits (Brown et al., 2000; Livingston and Garrido, 2004; Koudouri, 2004). 
This Basin is for the most part currently managed with more emphasis on current flows and uses than on future reservoir and aquifer stocks. So this description of unsustainable management approximately replicates the way water is currently managed in the Basin, in which little thought is given to water stocks available for future generations. ${ }^{3}$ No part of the current Law of the River described above explicitly calls for maintaining or increasing storage of the basin's water stocks.

\subsubsection{Sustaining Natural Capital}

Freshwater supplies in most watersheds fluctuate considerably from period to period. Even without human intervention, streamflows and aquifers can experience considerable fluctuations over the short, medium, and long term. For our purposes, we characterize the sustaining long term natural capital as occurring when any water management program succeeds in returning each Basin reservoirs to at least 80 percent of maximum storage capacity ${ }^{4}$ and also returns all aquifers to their starting (2010) levels by then end of the 20 year planning period. The Basin's total reservoir storage at the beginning of 2010 was about 1.1 million acre feet, 22 percent of its maximum storage capacity. So the requirement of sustaining natural capital would raise terminal period reservoir storage levels by about 3 million acre feet compared to 2010 conditions.

\footnotetext{
${ }^{3}$ However, the City of Albuquerque in 2008 completed a surface water treatment plant in which the City's reliance on the local depletable aquifer was greatly reduced.

${ }^{4}$ The baseline policy of 'Unsustainable Natural Capital,' desribed above, sets no requirement whasoever for returning any of the basin's reservoirs to any level at the end of the planning horizon. However for a policy of 'Sustaining Natural Capital,' described here, a requirement of returning reservoirs 80 pecent of maximum storage capacity might be too demanding, too artificial, or both. Historically, many reservoirs in the basin almost never reached 80 percent of maximum capacity. Reservoirs in many of the world's dry regions are designed to be oversized to deal with short wet periods in addition to capturing intra- and inter-year carryover storage; One way to define reservoir sustainability that's common in the reservoir optimization literature is to require that they return to their starting levels. Yet, this, too is artificial: starting levels may be unusually low because of recent droughts, so they are hardly a target for sustainability. They may also be too high because of recent floods, so they, too, are unrealistic as a sustainability target. Any reservoir sustainability target raises hard questions.
} 


\subsubsection{Renewing Natural Capital}

Both the principle and implementation of sustainable water institutions are subjects of intense debate.

One dimension of that debate focuses on the substitutability between the economy and the

environment or between natural capital and manufactured capital, a debate often couched in terms of weak versus strong sustainability (e.g., Tietenberg, 2009). For purposes of this paper, we view a policy that renews the basin's natural capital in water in terms of the basin's water stocks. Our approach recognizes that the existing stock of water must be maintained and enhanced because the functions it performs cannot be duplicated by other resources. ${ }^{5}$ We consider capital stock renewal as requiring the basin's terminal period reservoir storage to reach 90 percent of their maximum capacity, about half a million acre feet more terminal storage than achieved under the sustainable policy. ${ }^{6}$ In addition the four major regional aquifers under this scenario must return to at least as high a level as occurred under the policy that sustains natural capital described above.

For all three policies, water inflows produce stochastic supply levels to the basin for twenty consecutive future years, 2010-2029. That is, the model starts out with very low reservoir levels in 2010 produced by several sequential dry years. These current starting conditions are combined with the assumption that inflow conditions over the next ten consecutive years will equal to long term mean inflows at each of the headwater (inflow) nodes for the period of record. Inflow variation from one year to the next matches historical variance for the period of record. Climate change is addressed simplistically by reducing mean inflows in the last ten years of the model to $95 \%$ of their historical mean while

\footnotetext{
${ }^{5}$ This ignores the possibility of importing water from other basins, but recognizes that these imports, if carried out, would impose considerable environmental, economic, and political cost.

${ }^{6}$ The standard of 90 percent of maximum capacity poses all the problems of using 80 percent. However one justification is the recognition that 90 percent would provide an additional 500,000 acre feet of storage compared to 80 percent. That addition could be a cushion for dealing with future climate change that produces significantly less inflow to the Basin than produced under historical inflow patterns.
} 
maintaining historical year to year inflow variance. Many other approaches could be used to examine potential impacts of climate change.

\subsection{Institutions v. Policies}

The four existing institutions described above are quite important and are not trivialized by any of the three US states involved. The four institutions amount to constraints that define or limit the basin's water use patterns. Those four institutions (Law of the River) are required to be followed for all three policies we analyze, also described above. These four institutions are absolute requirements that are maintained throughout our policy analysis. All four are respected and enforced throughout the basin, regardless of cost or consequence. All four are constraints that are satisfied for the entire period of our analysis, reflecting the recent historical administration of water in the basin. These institutions are required to be enforced and are independent of which people, nations, or water users have more political strength or influence. By contrast, we describe three water sustainability policies as three competing water resource management aims. No more than one can of the three policies can occur at any one time. Each of those three policies respects all four existing institutions described above. These policies reflect three competing targets that could influence the long-term management of the basin's water. Each has an economic cost of its implementation that we present in the results.

\subsection{Measures to Implement Policies}

\subsubsection{Water Rights Adjudication}

Clear definition of the property right to use water can be an important foundation for a range of policies that can could support and sustain a river basin's future water supplies. Water rights adjudications are important because they can clarify property rights to use water as well as simplify administration of programs to limit current water uses to sustain future supplies. A stream adjudication settles all claims 
of water right holders with respect to each other within a particular water system, such as a river basin. For example, in the US, a stream adjudication is typically a legal process conducted through the courts used to determine the extent and validity of existing water rights. It can determine rights to either surface water or groundwater. It creates no new wet water. It merely establishes existing water rights, often in terms of priorities among the competing users who claim the right to use water from a streamaquifer system. An adjudicated water rights for any user is defined as the right to take water from the system. That right can vary according to the basin's water supply level. An adjudication is a mechanism to provide legal certainty for water right holders. When a court adjudication confirms a water right, that right becomes enforceable against other water users and can be protected from impairment by illegal non-adjudicated users.

Adjudicated rights are regulated in favor of senior water right holders during times of water shortage induced by drought or climate change. Adjudication provides a foundation for managing the use of water in an orderly way, especially important when water supplies vary from one period to the next. Adjudicated stream systems greatly simplify the process of water right transfers to support sustaining aquifers and reservoirs of the kind described in this paper. In fact, water right transfers in all three of the Basin's US states are both legal and common. The Cities of Albuquerque and Las Cruces, New Mexico have both entered the market for land/and or water several times since the 1980s to purchase farms and/or farm water to firm up their future supplies to meet their urban demands. A considerable amount of West Texas farm water use has also been transferred to the rapidly growing City of El Paso Texas since the 1980s. So in this Basin, market-based water transfers from farms to cities have been for many years a common and ongoing institution for adapting to growing urban demands in the face of limited supplies. 
When the legal clarity of water rights suffers from a cloud of uncertainty, common in non-adjudicated streams that typically occur outside the western world, it's difficult to assure that a water right purchase for aquifer recharge actually achieve its mission by reducing current uses. Without reducing current uses, an aquifer will see little additional recharge, so the water right purchase will have little effect. A recently published paper shows how to calculate the impacts and economic benefits of adjudicating a stream system in the case where adjudicated water rights do not currently exist (Torell and Ward, 2010).

\subsubsection{Payment for Sustainability Services}

We introduce the label Payment for Sustainability Services (PSS) as a broad label for any kind of marketbased mechanism used to redirect current water depletions for urban or agricultural back into recharge of aquifers or filling reservoirs. For the purposes of this paper, we define PSS as a voluntary transaction where a well-defined water right buyer retires ${ }^{7}$ an existing use of water, and uses that water to recharge an aquifer or refill a reservoir by more than the recharge that would have otherwise occurred. Where a water rights system currently exists through a formal adjudication or other culturally compatible mechanism that recognizes property rights, PSS could offer an efficient policy instrument for recharging water systems for sustainability. In the Rio Grande Basin, the two largest water users are farms and cities. A PSS buyer could be the state, an environmental organization, a city, or a group of farmers, any of whom is willing to pay to sustain or renew the basin's aquifers and/or reservoirs.

PSS buyers could retire surface water or groundwater use rights. ${ }^{8}$ With surface water rights retired, the hydrologic effect of a PSS is to reduce the use of surface diversions, for which water savings from

\footnotetext{
${ }^{7}$ Sometimes short term "contract water" can be purchased without buying the water right. A water right is the right to continue using water for the indefinite future, while a contract to use water carries no such right.

${ }^{8}$ When a groundwater right is bought, groundwater extractions (abstractions) are reduced. So if the PSS buyer bought a groundwater right, there is no need to recharge the aquifer with the purchased water, since the reduced pumping would effectively do the recharging.
} 
reduced use could be re-injected into a regional aquifer. The retirement would reduce overall surface diversions. Since the PSS as described here would not be used for current (beneficial) use, it would likely need a legislative authority to define PSS as a beneficial use. In regions of the world where water law is based on the prior appropriation system, such as most of the American west, lacking the label of beneficial use presents a problem for sustaining water stocks. Lacking the tag of beneficial use, aquifer recharge through PSS purchases risks presenting a similar legal challenge as seen by instream flow rights when instream flow is not defined as a beneficial use of water.

\subsubsection{Cap and Trade}

Cap and trade arrangements are becoming increasingly common in water resources management as a market trading mechanism to move water to sustainable uses. Cap and trade is a potentially workable policy instrument to move water into more sustainable uses in communities where formal water rights systems do not currently exist. A recent paper by Speed (2009) described efforts in China by water planners who are beginning to take steps down this path. Cap and trade could be especially attractive in many developing countries that currently have no legal foundation supporting well-defined, secure, and transferable water rights assigned to water users.

In conditions where formal water rights do not exist, a cap and trade program could be used as a policy measure to sustain regional aquifers. If established in places where formal water rights do not currently exist, a cap and trade arrangement could have several features that promote the movement of water into sustainable uses. It could be a culturally acceptable way to reduce water use by sending the right water price signals to irrigators and to urban water suppliers. Under the program, all farmers could be assigned a water entitlement per unit land irrigated, namely the cap. Urban water suppliers could be 
assigned an equivalent cap, based on a politically negotiated level of water need for basic subsistence needs per household.

The cap could be established for both agriculture and urban users based on a presumed right to a base level of subsistence water use. For example, in agriculture, something like 1.2 meters depth per unit land per year could be assigned as a base water use right for an amount of land required for a subsistence level of food security. That base right could be assigned to every farmer that demonstrated historical irrigation for a set amount of recent years. While important details obviously need to be worked out with considerable care, the amount chosen for the cap in agriculture could be based on the full yield surface irrigation requirements of all but the most water-intensive crops, like sugar cane, rice, or alfalfa. A higher cap could be assigned to farmers or urban utilities in areas where higher temperatures produced higher evaporation and greater crop or landscape evapotranspiration (ET). Under a cap and trade arrangement, any water use in excess of the cap would be legal, but would also require a purchase of water from a willing seller at a price reflecting the opportunity cost of water taken from that use. For example, Gohar and Ward (2010) describe in detail some of the challenges surrounding trades of water for cash for irrigated agriculture in Egypt. A cap and trade program avoids the most undesirable effects of government-administered prices, namely that administered prices can be unjust as well as rarely signaling the real scarcity of water.

Under a cap and trade arrangement, market forces rather than government edict would establish the price of water. The market price of tradable water to be purchased for aquifer recharge would vary from time to time, as the scarcity of water or its economic value changed. These changes could be brought about from any adjustments that affected any crop's price, yield, or production costs. It could also fall 
with advances in plant genetics or irrigation engineering that reduced any crop's water use or application requirements.

\section{Results}

\subsection{Reservoir Storage}

Table 1 shows reservoir storage patterns across the basin associated with each of the three water management policies considered. The first policy is the unsustainable institution described above. The second policy returns each reservoir to 80 percent of its maximum storage in the last period combined with requiring each regional aquifer's storage in the last period meeting or exceeding starting 2010 values. The third policy returns all reservoirs to 90 percent of maximum storage with each regional aquifer's last period storage at least as high as terminal period storage under the second policy.

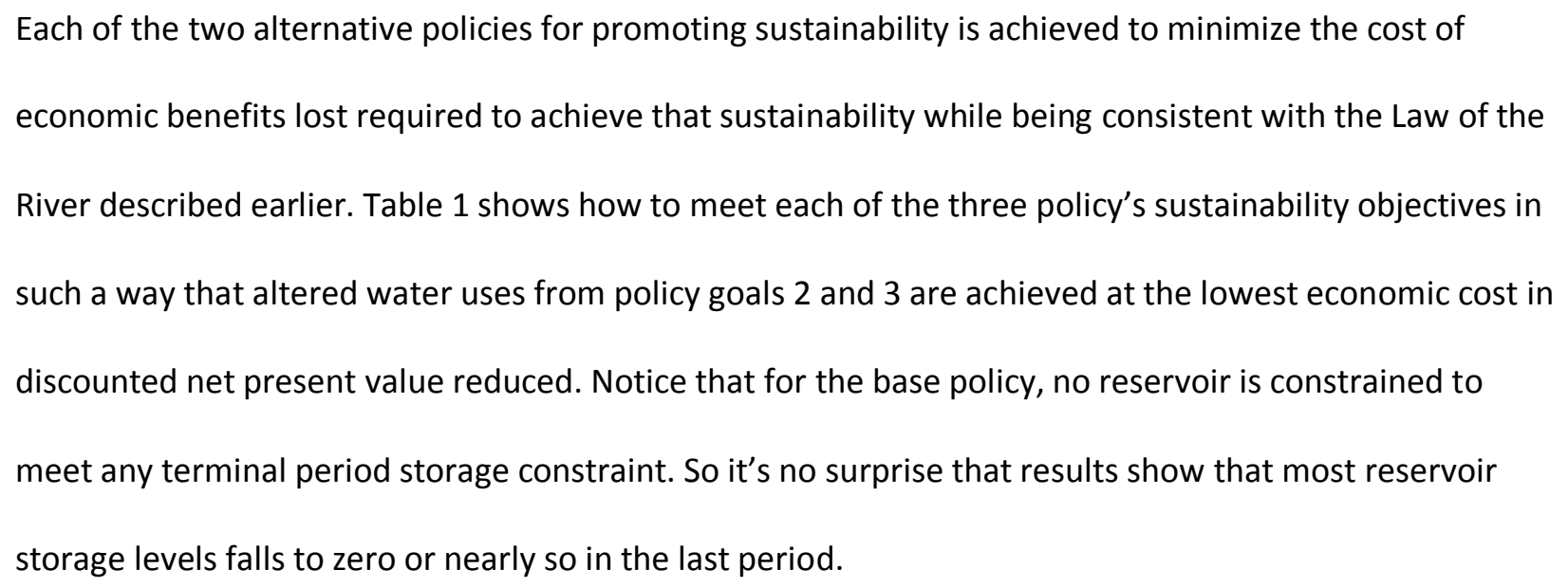

For each of the two alternative policies, the table shows that sustainability targets are met on a basinwide level by sharing responsibilities for achieving policy goals across reservoirs, but not requiring any particular performance for any single reservoir. Like many other shortage sharing rules, the table shows that for each of the two alternative sustainability policies, the optimal strategy for ensuring 
sustainability is to avoid equal sharing of responsibilities among reservoirs. This occurs because different reservoirs have different characteristics. Some are high elevation reservoirs in steep deep canyons, while others are shallower low elevation reservoirs with higher evaporation rates. Managers use each reservoir to bear the responsibility of contributing to current use and future sustainability by specializing in its unique comparative advantage.

Results show that the hottest (lowest elevation) reservoir in the upper part of the basin (Cochiti) bears the least responsibility for storing water under the policy of sustaining natural capital (policy alternative 1) among the four upper Basin reservoirs: Heron, El Vado, Abiquiu, and Cochiti. Those top four reservoirs store water for delivery to New Mexico under the Rio Grande Compact. Among the four, Cochiti has the highest evaporation rate. So if those four New Mexico reservoirs as a group do not all need to return to their maximum capacity, unused storage is largest at Cochiti Reservoir, while the other three use the largest part of their capacity to store water, because of their lower evaporation losses. However, the second alternative policy of renewing natural capital requires a larger amount of terminal period storage in the reservoir system as a whole. So Cochiti sees its average storage increase from 119,000 acre feet under alternative policy 1 (sustaining natural capital) to 556,000 acre feet stored under alternative policy 2 (renewing natural capital). Results shown in table 1 affirm widely-held knowledge of experienced water managers and water users who are aware of the important role of specialization. Each reservoir should be managed to make its best contribution to achieving overall Basin's mission of sustainability. Assigning a different responsibility across reservoirs occurs for two reasons: 
First, considerably lower evaporation occurs at the three upper basin reservoirs. That allows them to contribute to achieving more terminal period storage, losing the least water to evaporation. This allocation of responsibility can be seen as putting water in the reservoir (bank) while minimizing the negative evaporation (interest) rate. Requiring lower elevation reservoirs to share responsibility by increasing their storage volume would have incurred a cost of greater evaporation losses, i.e., a more negative interest rate. Rather than losing much of the lower basin reservoir storage to evaporation, that potential evaporation could be put to beneficial use for cities, irrigation, and the environment. Viewing the complete system of reservoirs as a system of banks, it makes hydrologic, economic, and political sense to put water in those banks that pay the lowest negative interest rate.

The second reason that it's economically efficient to use upper basin reservoirs to support sustainability goals is the considerably greater opportunity for water reuse that occurs at the upper elevation reservoirs. Their higher reuse occurs because many downstream users rely on the multiple uses of their releases through cascading return flows. For both reasons, operation of a system of reservoirs in series is often driven by a practical rule of thumb: fill upstream reservoirs first, in order to minimize spill losses, since the spills from upstream reservoirs can then be collected by the downstream ones (Lund and Guzman, 1998).

\subsection{Aquifer Storage}

Table 2 shows parallel results for the basin's four major aquifers that were shown in Table 1 for reservoirs. Reservoirs and aquifers have different hydrologic and economic properties, so managers can operate reservoirs and aquifers to contribute water management goals in different ways. The four regional aquifers shown are (1) the San Luis Valley, Colorado, aquifer, (2) Central New Mexico Aquifer 
near Albuquerque, (3) Mesilla Bolson including the Las Cruces area, and (4) Hueco Bolson in west Texas and southern New Mexico. Both these last two aquifers dip into to northern Mexico.

Aquifer locations with large levels of high economic valued pumping for urban water use occur in and near Albuquerque (Central New Mexico Aquifer) and El Paso (Hueco Bolson). Lower valued pumping occurs in irrigated agriculture at the San Luis Valley, Colorado and also by irrigators at the Elephant Butte Irrigation District, New Mexico (Mesilla Bolson). Little to no pumping capacity is currently developed at either the Middle Rio Grande Conservancy, New Mexico, or for west Texas agriculture. Constraints that require sustainable aquifer use for the basin as a whole will be borne less by urban than by irrigation water users. This occurs because a much lower price elasticity of demand for urban use than for irrigation gives rise to higher urban benefits lost from water not pumped. For all four regional aquifers, ending period storage levels are constrained to be at least as high as 2010 levels. That is, no additional pumping for the twenty year period of analysis is permitted under either of the two alternative policies than pumping that would reduce terminal period storage lower than 2010 starting levels. Without this requirement, a policy that raises the terminal period reservoir storage levels would produce greater groundwater pumping as a compensation for reduced opportunities to use reservoir water.

Table 2 shows that a regional policy requiring greater levels of sustainable water stocks results in irrigated agriculture using less surface water. This result occurs for both irrigated areas near the urban centers of Albuquerque and El Paso. Both of those irrigated areas are primarily surface irrigated. So, much of the aquifer recharge that would occur with heavier reservoir depletion under the base policy falls off as sustainability targets increase. Reduced irrigation associated with less reservoir water 
available for use means that aquifer recharge no longer takes place compared to recharge that would have occurred. Since agriculture contributes less to aquifer recharge as land is taken out of production, that aquifer recharge must be made up by reduced pumping by the two major cities as sustainability targets become more ambitious. This happens. Raising the terminal period storage volume for the basin's reservoirs requires both urban areas to pump less to compensate for the reduced aquifer recharge from irrigated agriculture.

For the policy requiring sustained natural capital, agricultural recharge of the aquifer falls by 284,000 acre feet near Albuquerque and by 319,000 acre feet near El Paso by the end of the twenty year period of analysis. For the case of renewing natural capital, irrigation recharge falls by 517,000 acre feet near Albuquerque and by 319,000 acre feet again near El Paso compared to a policy of no sustainability. For both these urban areas, urban water prices increase in the face of greater sustainability requirements by enough to take the pressure off these two aquifers, as tables 3-5 show in more detail.

\subsection{Unsustainable Natural Capital}

Table 3 presents results that reflect the basin's current management institutions, in which no policy requires a sustained performance for any water stocks anywhere in the Basin. There are no terminal period storage requirements for any reservoir or aquifer. Compared to the two alternative policies, it shows the highest water depletions over the 20 year planning period, producing about 1.40 million acre feet depleted per year on average summed over the basin. Because it shows the highest quantity of water used, it also shows the greatest discounted net present value of those benefits, about $\$ 608$ 
million per year summed over uses and averaged over years. ${ }^{9}$ These results are based on a simple maximization of the present value of total basinwide net benefits. The only background constraints required are defined by the Law of the River described earlier while subjecting the basin to the required hydrologic physical water balance.

The table also shows that the bulk of water depletion is contributed by irrigated agriculture, consuming about 86 percent of the basin's total use. Nevertheless the lion's share of the basin's economic benefits accrue to urban users, about three quarters of the total. That total includes a considerable economic productivity of reservoir-based recreation. This large share of benefits calculated for urban uses occurs because of the very low price elasticity of demand for urban uses and its associated high consumer surplus. That high consumer surplus produced by urban water consumption reflects a high willingness to pay for urban water compared to actual payments made for water bills to the Albuquerque and El Paso water utilities. Marginal net economic values of water for urban uses are low because both utilities supply water at a price close to their marginal cost of supply, and they deliver all demands at those prices. Still, total net economic benefits from urban water use are considerably higher than equivalent benefits of water used in irrigated agriculture.

Another interesting observation regarding urban and agricultural uses is that both marginal benefits (price) and marginal costs are much higher in urban than agricultural uses. However marginal net

\footnotetext{
${ }^{9}$ Only benefits of water use and water environments over the 20 year time horizon are measured. So the model treats as zero all future benefits outside the 20 year time horizon. There is zero scrap value for unused water. Without constraints requiring sustainable future water stocks, the model tends to drain reservoirs and pump aquifers to the point of zero discounted marginal net benefit. For these reasons, greater sustainability constraints are achieved at the cost of reduced benefits over the 20 year time horizon. Another way to account for sustainability not used for this paper is to specify an infinite time horizon model driven by a zero discount rate in which discounted net present value is made as high as possible.
} 
benefits for the two classes of use are more nearly equal (not shown). In fact, with sufficiently large headwater flows and sufficiently few institutional constraints to interstate water allocations, marginal net benefits will be zero for all urban, agricultural, and even environmental locations. In that case, marginal benefits of all uses and all environments are equal to marginal costs. These conditions have rarely occurred in the Rio Grande Basin, but may have nearly occurred in the mid 1980's when all reservoirs were full, aquifers were well-recharged, and snowpack runoff was above average for several years running.

\subsection{Sustaining Natural Capital}

Table 4 presents the current economic cost incurred by enacting policies that would sustain the basin's natural capital in water. The table shows a lower value of discounted net present value of benefits over the 20 year planning period by requiring the basin's reservoirs to return to 80 percent of their capacities with aquifers suffering no net depletions compared to 2010 levels.

Results show that a modest loss in present value of net benefits from water use and water environments are required to support a sustainable natural capital of water. That loss can be computed by comparing $\$ 608$ billion per year under the base policy to $\$ 571$ billion under the policy of sustaining natural capital in water, resulting in a basinwide loss of $\$ 37$ billion per average year in discounted net present value. That loss in economic benefits is about six percent of total water-related benefits under the base policy. Total annual average depletions for the basin equal 1.20 million acre feet per year for the 20 years when sustainable aquifer and reservoir management is practiced. By comparison to table 3 in which there is 'no management' to secure a sustainable future, total ET is 1.40 million acre feet per year. This means that sustainable management of water stocks results in about 14 percent less water 
depleted each year over the 20 year horizon. The much smaller percentage loss in economic benefits compared to the percent reduction in the basin's ET indicates that the lion's share of water consumptive use reduction is borne by irrigated agriculture. This finding is expected: total economic costs of required adjustments are minimized when a given level of total use reduction is borne by irrigated agriculture than by urban uses. The larger value of water in urban areas than for irrigated agriculture is a signal that water trading could benefit both farms and cities in the search for policies that sustain natural capital.

\begin{abstract}
A comparison of table 3 and table 4 shows that 203,000 acre feet per year of the basin's overall reduction in water consumptive use from a sustainability requirement is achieved by ET reductions in irrigated agriculture. A much smaller 25,000 acre feet per year of consumptive use reduced by urban users. In fact, reservoir evaporation under the sustained policy actually increased by 31,000 acre feet per year, reflecting higher reservoir levels on average required to carry out a policy to sustain water's natural capital.
\end{abstract}

\title{
5.5 Renewing Natural Capital
}

Table 5 shows the economic costs incurred by enacting policies that would renew the basin's natural capital in water. The table shows that water use reductions are larger when those reductions are used to renew the basin's natural capital rather than merely sustain it. The table shows a larger loss in discounted net present value of benefits over the 20 year planning period when the basin's reservoirs are required to return to 90 percent of their storage capacities while each aquifer must produce terminal period levels at least as high as levels under a sustained policy. That loss is computed in the following way: $\$ 608$ billion per year with no sustainability required compared to $\$ 540$ billion when 
renewed capital stocks are required, for a basinwide difference of $\$ 68$ billion, for a total loss equal to about 11 percent of the baseline average annual total economic value of water.

Results shown in Table 5 reveal the economic price to pay for filling the basin's reservoirs by an additional 524,000 acre feet of storage and requiring aquifers to return to an equal level as levels achieved by a policy of sustaining the basin's water stocks. Total average water consumption per year for the basin is 1.18 million acre feet when renewed natural capital in water is set as the target. Under the base policy of no management, total consumption for the basin is 1.40 million acre feet. This comparison across policies means that renewing the natural capital in water stocks requires an average of about 22,000 acre feet reduced water use each year over the 20 year horizon than merely sustaining that capital. Like Table 4, Table 5 shows a much smaller reduction in economic benefits (11 percent) than reduced water use (16 percent) to renew stocks than when no sustainability is required. Again this result occurs because the economic costs of renewing the capital stock are minimized when more water is retired from agriculture than from urban use.

\section{Discussion}

Our findings show that economically efficient policies provide no guarantee of being sustainable. That is, ensuring economic efficiency in the sense of maximizing discounted net present value of uses and environments provides no guarantee of sustainability. In addition, sustainability of natural capital can be achieved with an economically inefficient use pattern over the period of analysis. So merely designing a sustainable policy provides no guarantee of conventionally defined economically efficiency in water management over the period of analysis. This paper has described an economically efficient allocation of current water uses for sustaining reservoirs and aquifers over a 20 year period in North America's 
upper Rio Grande Basin. That allocation is efficient in the sense that it minimizes the economic sacrifice required to sustain or renew the basin's water stocks while being consistent with the basin's four most important existing water institutions. However an important and unanswered question centers on what institutions or policies could bring about these two kinds of sustainability.

One way to achieve the sustainability objectives described here is a cap and trade arrangement. Water rights in this basin are typically held as private property. These rights need to be adjudicated to be effective in recharging the basin's water stocks. Under a cap and trade program, future transfers of water or water rights to new uses could be accompanied by a requirement to take some specified percentage of that transfer out of production. For example, with a 20 percent transactions cost imposed on all transfers, a transfer of 10 acre feet of water from an existing use will only allow 8 acre feet of new use. The cost of this arrangement that shrinks overall use is shared by the seller and buyer, with little expense borne by the taxpayer. Such an arrangement could be implemented for either groundwater or surface water right transfers.

Another implementation of sustainability policy is through direct state intervention into the market. For example a reservoir or aquifer conservation fund could be established in which water or water rights are purchased by the state from existing right holders. The purchased water would be retired from existing uses and, then recharged into the aquifer or held in reservoirs. The cost of this plan would be borne by the taxpayer, which avoids a loss in asset value incurred by the buyer.

Finally, economic incentive policies can enhance sustainability and efficiency in river basin management. Getting the water prices right can lead to full cost recovery, reflecting both externalities and user costs. 
Other economic instruments can be applied, like subsidizing water conservation measures. Examples include subsidizing the purchase price of things like low flow showerheads, low flush toilets, waterefficient appliances, desert landscapes, and drip irrigation. Regardless of which institution is used to renew the basin's water stocks, there is a light at the end of the tunnel. After the basin's stocks are recharged, future water uses and environments can rely exclusively on renewable sources of water, with no need to continue reducing use to raise the basin's water stocks.

\section{Conclusions}

Integrated river basin management is high on the international political agenda. World-wide, sustainable water management and reductions in water and related food poverty have become top priorities. Hydroeconomic models offer one resource for the design sustainable water management plans. This paper has addressed that challenge by describing the design and application of an integrated basin-scale constrained optimization analysis for water allocation and use patterns for the Rio Grande Basin of North America.

The principle of designing resilient institutions to support sustainable river basin management continues to receive widespread international attention. Despite that considerable support, the thorny issue of costs associated with that management nearly always receives scrutiny when current water uses are reduced to support implementation of sustainability goals. Understandably managers and stakeholders who benefit from heavy water use in irrigated agriculture in addition to ratepayers in large urban areas resist proposals to have their current water uses reduced for which the main beneficiaries are water users of future generations who pay no current taxes. When sustainable management of water resources is implemented by policies that would incur a high cost of current water uses displaced, water 


\begin{abstract}
managers and consumers have a natural interest in seeing reliable information on the size of those costs. This paper has provided that information, in a limited way, for one basin.
\end{abstract}




\section{References}

Abdullaev, I., J. Kazbekov, H. Manthritilake, and K. Jumaboev. 2011. Water User Groups in Central Asia: Emerging Form of Collective Action in Irrigation Water Management. Water Resources Management 24:1029-1043.

Ako, A. A., G. E. T. Eyong, and G. E. Nkeng. 2011. Water Resources Management and Integrated Water Resources Management (IWRM) in Cameroon. Water Resources Management 24:871-888.

Al-Omari, A., S. Al-Quraan, A. Al-Salihi, and F. Abdulla. 2009. A Water Management Support System for Amman Zarqa Basin in Jordan. Water Resources Management 23:3165-3189.

Berger, T., R. Birner, J. Diaz, N. McCarthy, and H. Wittmer. 2007. Capturing the complexity of water uses and water users within a multi-agent framework. Water Resources Management 21:129-148.

Booker, J. F. 1995. Hydrologic and Economic Impacts of Drought under Alternative Policy Responses. Water Resources Bulletin 31 889-906.

Booker, J. F., A.M. Michelsen, and F.A. Ward 2005. Economic Impact of Alternative Policy Responses to Prolonged and Severe Drought in the Rio Grande Basin. Water Resources Research 41:W02026.

Booker, J. F., and R. A. Young. 1994. Modeling Intrastate and Interstate Markets for Colorado River Water Resources. Journal of Environmental Economics and Management 26:66-87.

Brown, G. M. 2000. Renewable natural resource management and use without markets. J. Econ. Lit 38:875-914.

Brown, T. 1990. Marginal Economic Value of Streamflow: A Case Study for the Colorado River Basin. Water Resources Research 26:2845-2859.

Burke, S. M., R. M. Adams, and W. W. Wallender. 2004. Water Banks and Environmental Water, and Demands: Case of the Klamath Project. Water Resources Res 40: 2004.

Cai, X., and M. W. Rosegrant. 2004. Irrigation Technology Choices under Hydrologic Uncertainty: A Case Study from Maipo River Basin, Chile. Water Resources Research 40:W04103, doi:04110.01029/02003WR002810.

Calizaya, A., O. Meixner, L. Bengtsson, and R. Berndtsson. 2011. Multi-criteria Decision Analysis (MCDA) for Integrated Water Resources Management (IWRM) in the Lake Poopo Basin, Bolivia. Water Resources Management 24:2267-2289.

Characklis, G. W., R.C. Griffin and P.B. Bedient. 1999. Improving the Ability of a Water Market to Efficiently Manage Drought. Water Resources Research 35:823-831.

Chikozho, C. 2008. Globalizing integrated water resources management: A complicated option in Southern Africa. Water Resources Management 22:1241-1257. 
City of Albuquerque Water Utilities. 2011. On the web at: http://www.cabq.gov/water/.

De Stefano, L. 2011. International Initiatives for Water Policy Assessment: A Review. Water Resources Management 24:2449-2466.

Draper, A. J., Jenkins, M.W., Kirby, K.W., Lund, J.R., and Howitt, R.E. 2003. Economic Engineering Optimization for California Water Management. Journal of Water Resource Planning and Management 129:155-164.

El Paso County Water Improvement District \#1. 2011. On the web at: www.epcwid1.org.

El Paso Water Utilities. 2011. On the web at: http://www.epwu.org.

Elephant Butte Irrigation District. 2011. On the web at: http://www.ebid-nm.org.

El-Naqa, A., and A. Al-Shayeb. 2009. Groundwater Protection and Management Strategy in Jordan. Water Resources Management 23:2379-2394.

Eum, H. I., and S. P. Simonovic. 2011. Integrated Reservoir Management System for Adaptation to Climate Change: The Nakdong River Basin in Korea. Water Resources Management 24:3397-3417.

Falkenmark, M. 2007. Shift in thinking to address the 21st century hunger gap - Moving focus from blue to green water management. Water Resources Management 21:3-18.

Fang, C. L., C. Bao, and J. C. Huang. 2007. Management implications to water resources constraint force on socio-economic system in rapid urbanization: A case study of the hexi corridor, NW China. Water Resources Management 21:1613-1633.

Flugel, W. A. 2007. The adaptive integrated data information system (AIDIS) for global water research. Water Resources Management 21:199-210.

Gohar, A., and W. F.A. 2010. Gains from expanded irrigation water trading in Egypt: an integrated basin approach. Ecological Economics 69:2535-2548.

Gürlük, S., and F. A. Ward. 2009. Integrated basin management: water and food policy options for Turkey. Ecological Economics 68:2666-2678.

Hawkes, J. M., and J. D. Libbin. 2011. Cost and Return Estimates. November 12 at http://aces.nmsu.edu/cropcosts/

Jenkins, M. W., J.R. Lund, R.E. Howitt, A.J. Draper, S.M. Msangi, S.K. Tanaka, R.S. Ritzema, and G.F., and Marques. 2004. Optimization of California's Water System: Results and Insights. Journal of Water Resource Planning and Management 130:271-280. 
Koch, H., and U. Grunewald. 2009. A Comparison of Modelling Systems for the Development and Revision of Water Resources Management Plans. Water Resources Management 23:1403-1422.

Koundouri, P. 2004. Current issues in the economics of groundwater resource management. Journal of Economics Surveys 18:703-740.

Letcher, R. A., A. J. Jakeman, and B. F. W. Croke. 2004. Model Development for Intgegrated Assessment of Water Allocation Options. Water Resources Research 40:W05502, doi:05510.01029/02003WR002933.

Livingston, M. L., and Garrido, A. 2004. Entering the policy debate: an economic valuation of groundwater policy in flux. Water Resources Research 40:W12SO2.

Lund, J., and Guzman, J. 1999. Some Derived Operating Rules for Reservoirs in Series or in Parallel. Journal of Water Resources Planning and Management 125:143-153.

McCarl, B. A., C.R. Dillon, K.O. Keplinger, and R.L. Williams. 1999. Limiting Pumping from the Edwards Aquifer: An Economic Investigation of Proposals, Water Markets, and Spring Flow Guarantees. Water Resources Research 35:1257-1268.

Michelsen, A., T. McGuckin, and D. Stumpf. 1999. Nonprice Water Conservation Programs as a Demand Management Tool. Journal of the American Water Resources Association 35:593-602.

Middle Rio Grande Conservancy District. 2011. On the web at: http://www.mrgcd.com.

Molina, J. L., J. L. G. Arostegui, J. Benavente, C. Varela, A. de la Hera, and J. A. L. Geta. 2009. Aquifers Overexploitation in SE Spain: A Proposal for the Integrated Analysis of Water Management. Water Resources Management 23:2737-2760.

Mukhopadhyay, B., and A. Dutta. 2011. A Stream Water Availability Model of Upper Indus Basin Based on a Topologic Model and Global Climatic Datasets. Water Resources Management 24:4403-4443.

Murad, A. A., H. Al Nuaimi, and M. Al Hammadi. 2007. Comprehensive assessment of water resources in the united arab emirates (UAE). Water Resources Management 21:1449-1463.

National Research Council. 1997. Valuing Ground Water: Economic Concepts and Approaches. National Academic Press, Washington, D.C.

New Mexico Water Resources Research Institute. 2006. Rio Grande Compact Text.

Newlin, B. D., M.W. Jenkins J.R. Lund and R.E. Howitt. 2002. Southern California Water Markets: Potential and Limitations. Journal of Water Resource Planning and Management 128:21-32.

Pascual, P. 2007. Avoiding tragedies of the intellectual commons through Integrated Impact Assessments. Water Resources Management 21:2005-2013. 
Prodanovic, P., and S. P. Simonovic. 2011. An Operational Model for Support of Integrated Watershed Management. Water Resources Management 24:1161-1194.

Pulido-Velázquez, M., J. Andreu, and A. Sahuquillo. 2006. Economic Optimization of Conjunctive Use of Surface and Groundwater at the Basin Scale. Journal of Water Resource Planning and Management.

Pulido-Velázquez, M., M.W. Jenkins, and J.R. Lund, 2004. Economic Values for Conjunctive Use and Water Banking in Southern California. Water Resources Research, 40(3), W03401.

Ringler. C.J., J. von B., and M.W. Rosegrant. 2004. Water Policy Analysis for the Mekong River Basin. Water International 29:30-42.

Rio Grande Water Conservation District. 2011. On the web at: http://www.rgwcd.org.

Schulze, R. E. 2007. Some Foci of Integrated Water Resources Management in the"South" which are oftforgotten by the "North": A perspective from southern Africa. Water Resources Management 21:269294.

Silva-Hidalgo, H., I. R. Martin-Dominguez, M. T. Alarcon-Herrera, and A. Granados-Olivas. 2009. Mathematical Modelling for the Integrated Management of Water Resources in Hydrological Basins. Water Resources Management 23:721-730.

Tanaka, S. K., T. Zhu, J. R. Lund, R. E. Howitt, M. W. Jenkins, M. Pulido-Velazquez, M. Tauber, R. S., and Ritzema and I. C. Ferreira. 2006. Climate Warming and Water Management Adaptation for California. Climatic Change 76:361-384.

Tietenberg, T., and L. Lewis. 2009. Environmental and Natural Resource Economics. Prentice-Hall. 8th Edition.

Torell, G., and F. A. Ward. 2010. Improved Water Institutions for Food Security and Rural Livelihoods in Afghanistan's Balkh River Basin. International Journal of Water Resources Development 26:613-637.

van der Keur, P., H. J. Henriksen, J. C. Refsgaard, M. Brugnach, C. Pahl-Wostl, A. Dewulf, and H. Buiteveld. 2008. Identification of major sources of uncertainty in current IWRM practice. Illustrated for the Rhine basin. Water Resources Management 22:1677-1708.

Ward, F. A., J.F. Booker, and A. Michelsen. 2006. Integrated Economic, Hydrologic, and Institutional Analysis of Policy Responses to Mitigate Drought Impacts in the Rio Grande Basin. Journal of Water Resource Planning and Management: 488-502.

Ward, F. A., and M. Pulido-Velazquez. 2008. Incentive Pricing and Cost Recovery at the Basin Scale. Journal of Environmental Management.

Ward, F. A., R. A. Cole, R. A. Deitner, and K. A. Green-Hammond. 1997. Limiting environmental program contradictions: a demand systems application to fishery management. American Journal of Agricultural Economics 79:803-813. 
Ward, F. A., and M. P. Velázquez. 2008. Efficiency, equity and sustainability in a water quantity-quality optimization model in the Rio Grande basin. Ecological Economics 66:26-37.

Watkins, D. W. and M., D.A. . 2006. Economic-Based Optimization of Panama Canal System Operations. Journal of Water Resources Planning and Management 132:454-467.

Willis, D. B., and N.K. Whittlesey. 1998. Water Management Policies for Streamflow Augmentation in an Irrigated River Basin. Journal of Agricultural and Resource Economics 23:170-190.

Young, R. A. 2005. Determining the Economic Value of Water: Concepts and Methods. Washington D.C, USA: Resources For the Future.

Zarghaami, M. 2006. Integrated water resources management in polrud irrigation system. Water Resources Management 20:215-225.

Zarghami, M., A. Abrishamchi, and R. Ardakanian. 2008. Multi-criteria decision making for integrated urban water management. Water Resources Management 22:1017-1029. 


\begin{tabular}{|c|c|c|c|c|c|c|c|c|c|c|c|}
\hline \multirow{3}{*}{ Reservoir } & \multirow{3}{*}{ State } & \multicolumn{9}{|c|}{ Policy Alternative } & \multirow{3}{*}{$\begin{array}{c}\text { Reservoir } \\
\text { Storage } \\
\text { Capacity }\end{array}$} \\
\hline & & \multicolumn{3}{|c|}{$\begin{array}{c}\text { Base Policy: } \\
\text { Unsustainable } \\
\text { Institutions }\end{array}$} & \multicolumn{3}{|c|}{$\begin{array}{c}\text { Alternative 1: Sustaining } \\
\text { Natural Capital }\end{array}$} & \multicolumn{3}{|c|}{$\begin{array}{l}\text { Alternative 2: Renewing } \\
\text { Natural Capital }\end{array}$} & \\
\hline & & Start & End & Change & Start & End & Change & Start & End & Change & \\
\hline & \multirow{2}{*}{ NM } & \multicolumn{10}{|c|}{ (1000 ac-ft) } \\
\hline Heron & & 252 & 4 & -248 & 252 & 400 & 148 & 252 & 400 & 148 & 400 \\
\hline El Vado & \multirow{2}{*}{$\begin{array}{l}\text { NM } \\
\text { NM }\end{array}$} & 60 & 0 & -60 & 60 & 185 & 125 & 60 & 186 & 126 & 186 \\
\hline Abiquiu & & 181 & 4 & -177 & 181 & 1535 & 1354 & 181 & 1535 & 1354 & 1535 \\
\hline Cochiti & \multirow{3}{*}{$\begin{array}{l}\text { NM } \\
\text { NM } \\
\text { NM }\end{array}$} & 53 & 0 & -53 & 53 & 119 & 66 & 53 & 556 & 503 & 719 \\
\hline Elephant Butte & & 500 & 0 & -500 & 500 & 1810 & 1310 & 500 & 1895 & 1395 & 2065 \\
\hline Caballo & & 140 & 0 & -140 & 140 & 140 & 0 & 140 & 140 & 0 & 331 \\
\hline \multicolumn{2}{|l|}{ Total, Basinwide } & 1186 & 8 & -1178 & 1186 & 4189 & 3003 & 1186 & 4712 & 3526 & 5236 \\
\hline
\end{tabular}




\begin{tabular}{|c|c|c|c|c|c|}
\hline Regional Aquifer & State & Primary Use & $\begin{array}{l}\text { Base Policy: } \\
\text { Unsustainable } \\
\text { Institutions }\end{array}$ & $\begin{array}{l}\text { Alternative 1: } \\
\text { Sustaining } \\
\text { Natural Capital }\end{array}$ & $\begin{array}{l}\text { Alternative 2: } \\
\text { Renewing } \\
\text { Natural Capital }\end{array}$ \\
\hline 1. San Luis Valley Aquifer & CO & agriculture & 0 & 0 & 0 \\
\hline 2. Central New Mexico Aquifer Total & CO & & 2650 & 2650 & 2650 \\
\hline Central NM Aquifer - Albuquerque Metro & NM & urban & -405 & -121 & 111 \\
\hline Central NM Aquifer - MRG Conservancy & NM & agriculture & 3055 & 2771 & 2539 \\
\hline 3. Mesilla Bolson Total & NM & agriculture & 1790 & 1790 & 1790 \\
\hline 4. Hueco Bolson Total & TX & & -60 & 0 & 0 \\
\hline Hueco Bolson - El Paso Metro & TX & urban & -602 & -223 & -223 \\
\hline Hueco Bolson - El Paso Water District \#1 & TX & agriculture & 541 & 223 & 223 \\
\hline Total, Basinwide & & & 4380 & 4440 & 4440 \\
\hline
\end{tabular}




\begin{tabular}{|c|c|c|c|c|c|c|c|c|c|c|}
\hline State & \multirow{3}{*}{ Units } & $\mathrm{CO}$ & \multicolumn{5}{|c|}{ NM } & \multicolumn{2}{|c|}{$T X$} & \multirow{2}{*}{$\begin{array}{l}\text { Basin } \\
\text { Total }\end{array}$} \\
\hline Demand Region & & SLV & Albuquerque & MRGCD & EBID & $\begin{array}{c}4 \text { Upper } \\
\text { Reservoirs }\end{array}$ & $\begin{array}{c}2 \text { Lower } \\
\text { Reservoirs }\end{array}$ & El Paso & El Paso & \\
\hline Sector & & Agr & Urban & Agr & Agr & Recreation & Recreation & Agr & Urban & \\
\hline \multicolumn{11}{|l|}{ Hydrologic Performance } \\
\hline Water Consumed -- ET & \multirow{4}{*}{$1000 \mathrm{ac}-\mathrm{ft} / \mathrm{yr}$} & 612 & 56 & 288 & 199 & 64 & 17 & 102 & 62 & 1,401 \\
\hline Water Applied & & 1,225 & 188 & 670 & 393 & - & - & 237 & 207 & 2,920 \\
\hline Surface water & & 612 & 100 & 670 & 327 & - & - & 237 & 15 & 1,962 \\
\hline Groundwater & & 612 & 88 & 0 & 66 & - & - & 0 & 192 & 959 \\
\hline \multicolumn{11}{|l|}{ Agronomic Performance } \\
\hline Cropland in Production & \multirow{3}{*}{$\begin{array}{c}1000 \mathrm{ac} \\
\mathrm{ac}-\mathrm{ft} / \mathrm{ac} / \mathrm{yr} \\
\mathrm{ac}-\mathrm{ft} / \mathrm{ac} / \mathrm{yr}\end{array}$} & 205 & - & 63 & 91 & - & - & 47 & - & 405 \\
\hline Crop Water Use Rate - ET & & 3.0 & - & 4.6 & 2.2 & - & - & 2.2 & - & 3.5 \\
\hline Crop Water Application Rate & & 6.0 & - & 10.6 & 4.3 & - & - & 5.1 & - & 7.2 \\
\hline \multicolumn{11}{|l|}{ Urban Supply Performance } \\
\hline Water Price & \multirow{2}{*}{$\begin{array}{l}\text { \$US/1000 gal } \\
\mathrm{gal} / \mathrm{hshld} / \mathrm{day}\end{array}$} & - & 2.55 & - & - & - & - & - & 2.58 & - \\
\hline Per Household Use & & - & 377 & - & - & - & - & - & 321 & - \\
\hline \multicolumn{11}{|l|}{ Economic Performance } \\
\hline Total Net Benefits & \multirow{3}{*}{$\$$ US 1000/yr } & 45,099 & 246,191 & 22,890 & 36,613 & 19,250 & 934 & 26,432 & 210,769 & 608,179 \\
\hline From Water Use & & 45,099 & 246,191 & 22,890 & 36,613 & 0 & 0 & 26,432 & 210,769 & 587,994 \\
\hline From Water Environment & & 0 & 0 & 0 & 0 & 19,250 & 934 & 0 & 0 & 20,184 \\
\hline
\end{tabular}




\begin{tabular}{|c|c|c|c|c|c|c|c|c|c|c|}
\hline State & \multirow{3}{*}{ Units } & $\mathrm{CO}$ & \multicolumn{5}{|c|}{ NM } & \multicolumn{2}{|c|}{ TX } & \multirow{2}{*}{$\begin{array}{l}\text { Basin } \\
\text { Total }\end{array}$} \\
\hline Demand Region & & SLV & Albuquerque & MRGCD & EBID & $\begin{array}{c}4 \text { Upper } \\
\text { Reservoirs }\end{array}$ & $\begin{array}{l}2 \text { Lower } \\
\text { Reservoirs }\end{array}$ & El Paso & El Paso & \\
\hline Sector & & Agr & Urban & Agr & Agr & Recreation & Recreation & Agr & Urban & \\
\hline \multicolumn{11}{|l|}{ Hydrologic Performance } \\
\hline Water Consumed -- ET & & 591 & 43 & 261 & 103 & 26 & 86 & 42 & 50 & 1,203 \\
\hline Water Applied & $1000 \mathrm{ac}-\mathrm{ft} / \mathrm{yr}$ & 1,183 & 144 & 608 & 231 & - & - & 98 & 168 & 2,431 \\
\hline Surface water & & 591 & 100 & 608 & 231 & - & - & 98 & 78 & 1,706 \\
\hline Groundwater & & 591 & 44 & 0 & 0 & - & - & 0 & 89 & 724 \\
\hline \multicolumn{11}{|l|}{ Agronomic Performance } \\
\hline Cropland in Production & $1000 \mathrm{ac}$ & 198 & - & 50 & 50 & - & - & 19 & - & 318 \\
\hline Crop Water Use Rate - ET & $\mathrm{ac}-\mathrm{ft} / \mathrm{ac} / \mathrm{yr}$ & 3.0 & - & 5.2 & 2.0 & - & - & 2.2 & - & 3.8 \\
\hline Crop Water Application Rate & $\mathrm{ac}-\mathrm{ft} / \mathrm{ac} / \mathrm{yr}$ & 6.0 & - & 12.1 & 4.6 & - & - & 5.1 & - & 7.6 \\
\hline \multicolumn{11}{|l|}{ Urban Supply Performance } \\
\hline Water Price & $\$ U S / 1000$ gal & - & 4.25 & - & - & - & - & - & 2.58 & - \\
\hline Per Household Use & gal/hshld/day & - & 289 & - & - & - & - & - & 261 & - \\
\hline \multicolumn{11}{|l|}{ Economic Performance } \\
\hline Total Net Benefits & cus 1000 or & 43,553 & 233,450 & 24,532 & 26,248 & 15,271 & 1,420 & 18,133 & 208,368 & 570,975 \\
\hline From Water Use & 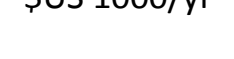 & 43,553 & 233,450 & 24,532 & 26,248 & 0 & 0 & 18,133 & 208,368 & 554,284 \\
\hline From Water Environment & & 0 & 0 & 0 & 0 & 15,271 & 1,420 & 0 & 0 & 16,691 \\
\hline
\end{tabular}




\begin{tabular}{|c|c|c|c|c|c|c|c|c|c|c|}
\hline State & \multirow{3}{*}{ Units } & $\mathrm{CO}$ & \multicolumn{5}{|c|}{ NM } & \multicolumn{2}{|c|}{ TX } & \multirow{2}{*}{$\begin{array}{l}\text { Basin } \\
\text { Total }\end{array}$} \\
\hline Demand Region & & SLV & Albuquerque & MRGCD & EBID & $\begin{array}{c}4 \text { Upper } \\
\text { Reservoirs }\end{array}$ & $\begin{array}{l}2 \text { Lower } \\
\text { Reservoirs }\end{array}$ & El Paso & El Paso & \\
\hline Sector & & Agr & Urban & Agr & Agr & Recreation & Recreation & Agr & Urban & \\
\hline \multicolumn{11}{|l|}{ Hydrologic Performance } \\
\hline Water Consumed - ET & & 591 & 32 & 239 & 98 & 37 & 94 & 42 & 48 & 1,182 \\
\hline Water Applied & $1000 \mathrm{ac}-\mathrm{ft} / \mathrm{yr}$ & 1,183 & 108 & 557 & 226 & - & - & 98 & 161 & 2,332 \\
\hline Surface water & & 591 & 100 & 557 & 226 & - & - & 98 & 73 & 1,645 \\
\hline Groundwater & & 591 & 8 & 0 & 0 & - & - & 0 & 88 & 687 \\
\hline \multicolumn{11}{|l|}{ Agronomic Performance } \\
\hline Cropland in Production & $1000 \mathrm{ac}$ & 198 & - & 45 & 49 & - & - & 19 & - & 311 \\
\hline Crop Water Use Rate - ET & $\mathrm{ac}-\mathrm{ft} / \mathrm{ac} / \mathrm{yr}$ & 3.0 & - & 5.3 & 2.0 & - & - & 2.2 & - & 3.8 \\
\hline Crop Water Application Rate & $\mathrm{ac}-\mathrm{ft} / \mathrm{ac} / \mathrm{yr}$ & 6.0 & - & 12.4 & 4.7 & - & - & 5.1 & - & 7.5 \\
\hline \multicolumn{11}{|l|}{ Urban Supply Performance } \\
\hline Water Price & \$US/1000 gal & - & 5.64 & - & - & - & - & - & 3.90 & - \\
\hline Per Household Use & gal/hshld/day & - & 218 & - & - & - & - & - & 251 & - \\
\hline \multicolumn{11}{|l|}{ Economic Performance } \\
\hline Total Net Benefits & Sus $1000 / v r$ & 43,553 & 203,902 & 23,599 & 29,038 & 15,900 & 1,465 & 18,109 & 204,926 & 540,491 \\
\hline From Water Use & 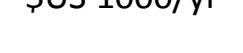 & 43,553 & 203,902 & 23,599 & 29,038 & 0 & 0 & 18,109 & 204,926 & 523,127 \\
\hline From Water Environment & & 0 & 0 & 0 & 0 & 15,900 & 1,465 & 0 & 0 & 17,365 \\
\hline
\end{tabular}


Click here to download colour figure: RG-schematic-feb-20/12. Sant Lut Valley, Ag
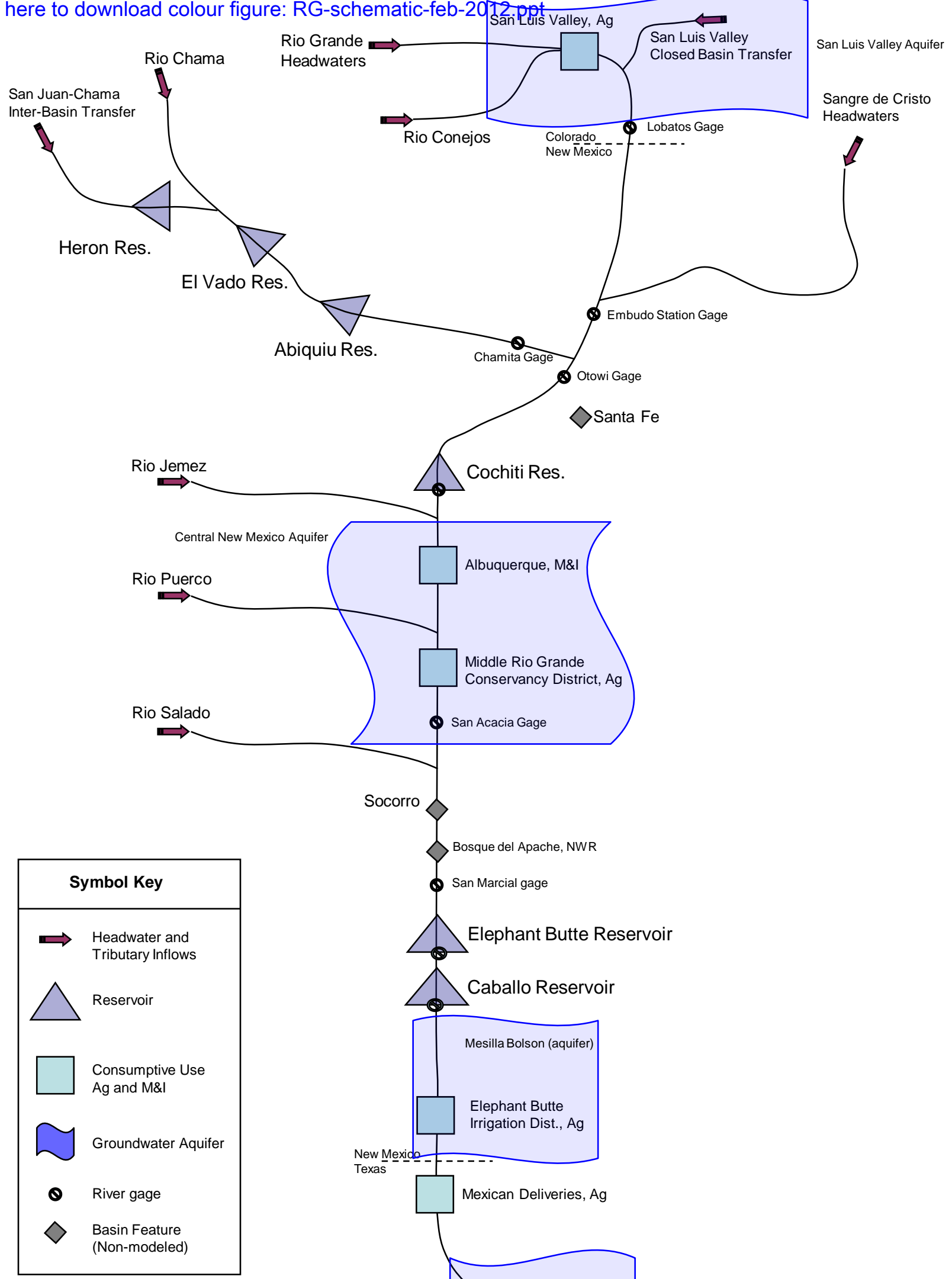

Figure 1: Rio Grande Basin Schematic

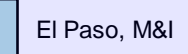

Hueco Bolson (aquifer)

El Paso Gage 